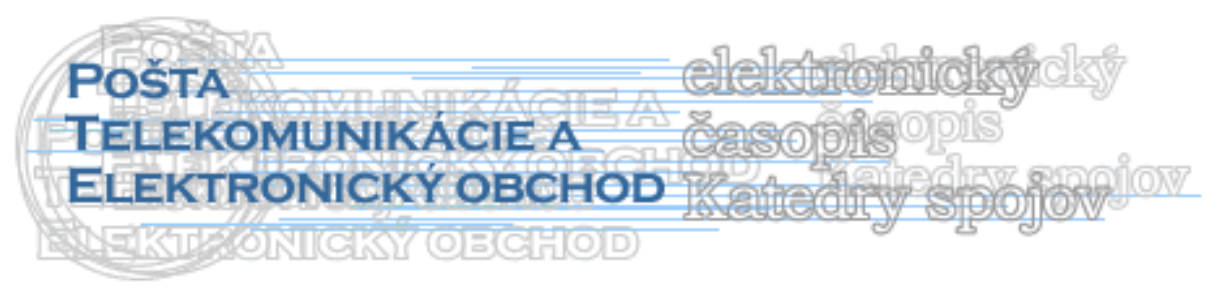

\title{
PODNIKANIE: SLOVENSKO VERZUS ZVYŠOK V4
}

\author{
Pavel Kaštánek*, Michal Gregorička*
}

Z dielne Svetovej banky každoročne vychádza štúdia „Doing Business“, ktorá hodnotí stav podnikatel'ského prostredia v krajinách celého sveta. Každoročne je do štúdie zahrnuté väčšie množstvo porovnávaných oblastí a súčasne rastie počet porovnávaných krajín.

Vol'ne dostupná analýza podnikatel'ského prostredia, ktorá bola vytvorená v minulom roku, porovnáva 145 krajín na základe siedmich oblastí podnikania, od zakladania podniku cez pružnost' pracovného trhu, legislatívne obmedzenia, prístup k úverom až po zrušenie podniku.

Najväčší vplyv na podnikatel'ské prostredie každej krajiny mali reformy, ktoré boli uskutočnené v roku 2003 - ich implementácia sa naplno mohla prejavit' až v roku 2004, za ktorý sú krajiny porovnávané. Slovensko získalo významné ocenenie „najreformnejšia krajina“" v oblasti podnikania. Najväčšie zmeny, ktoré Svetová banka dáva za príklad aj ostatným krajinám, Slovensko spravilo v oblasti flexibility pracovného trhu. Dobre si však počínalo aj $\mathrm{v}$ iných oblastiach - čas potrebný na založenie podniku sa v SR skrátil na polovicu, zavedený bol úverový register alebo skrátený proces vymáhania pohl'adávok.

Krajiny tzv. Vyšehradskej štvorky (V4) majú vel'a spoločného, ich vývoj v minulom storočí bol podobný - všetky patrili do „východného bloku“. Po páde komunizmu však začala každá krajina transformačný proces z inej pozície a tiež postup tejto transformácie na trhový mechanizmus bol rozdielny, čo spôsobilo rozdielnost' krajín z makroekonomického hl'adiska. Ked’že práve tieto štyri krajiny (Slovensko, Česká republika, Pol'sko, Mad’arsko) sú si v rámci rozšírenej EÚ najbližšie, porovnajme si stav podnikatel'ského prostredia podl'a Svetovej banky medzi nimi.

\section{Zakladanie podniku}

Založenie podniku je zavŕšením určitého postupu procedúr, ktorý okrem spotrebovaného času generuje náklady, nevyhnutné na založenie podniku. Legislatívne úpravy a byrokracia vytvárajú rozdiely v procese zakladania podnikov. Č́́m je začatie podnikania l'ahšie, tým sa podnikanie stáva dostupnejším - a to sa samozrejme premieta do zvýšenia rozvoju podnikania. Slovensko v roku 2004 patrilo medzi najlepších reformátorov v oblasti zakladania podniku. Úpravou zákonov zredukovalo čas založenia spoločnosti z 98 na 52 dní. Konkrétne založenie spoločnosti s ručením obmedzeným v praxi je možné aj $\mathrm{v}$ priebehu dvoch týždňov, čo radí Slovensko na úroveň krajín OECD. V rámci V4 si

\footnotetext{
* Ing. Pavel Kaštánek, Katedra spojov, Fakulta prevádzky a ekonomiky dopravy a spojov, Žilinská univerzita v Žiline, Univerzitná 1, 01026 Žilina, Slovenská republika, tel.: +421/41/5133100, fax: +421/41/5655615, e-mail: Pavel.Kastanek@fpedas.utc.sk

* Ing. Michal Gregorička, Katedra spojov, Fakulta prevádzky a ekonomiky dopravy a spojov, Žilinská univerzita v Žiline, Univerzitná 1, 01026 Žilina, Slovenská republika,
} 
Slovensko podl'a štúdie Doing Business nepočína najlepšie. Zakladanie podniku u nás síce vyžaduje najmenšie náklady, na druhej strane je však najpomalšie.

Tabul'ka 1 Založenie podniku na Slovensku v porovnaní so sledovanými krajinami

\begin{tabular}{|l|l|l|l|l|}
\hline Krajina & $\begin{array}{l}\text { Počet } \\
\text { procedúr }\end{array}$ & Čas (v dňoch) & $\begin{array}{l}\text { Náklady (v \% hrubého } \\
\text { domáceho príjmu na } \\
\text { osobu) }\end{array}$ & $\begin{array}{l}\text { Minimálny kapitál (v \% } \\
\text { GNI na osobu) }\end{array}$ \\
\hline Slovensko & 9 & 52 & $\mathbf{5 , 7}$ & 46,1 \\
\hline Česká republika & 10 & 40 & 10,8 & $\mathbf{4 4 , 5}$ \\
\hline Mad'arsko & $\mathbf{6}$ & 52 & 22,9 & 86,4 \\
\hline Pol'sko & 10 & $\mathbf{3 1}$ & 20,6 & 237,9 \\
\hline
\end{tabular}

\section{Prijímanie a prepúšt’anie zamestnancov}

Pružnost' pracovného trhu má v celkovom rozvoji krajiny vel'ký význam. Čím je trh flexibilnejší, tým menšiu istotu síce pre zamestnancov znamená, no v konečnom dôsledku vytvorí podstatne väčšie množstvo pracovných príležitostí a tak neistotu udržania zamestnania kompenzuje vel'kou šancou nájst' si po strate zamestnania v krátkom čase nové. Navyše rigidný pracovný trh má pre štát negatívne dôsledky $v$ raste nezamestnanosti a šedej ekonomiky. V oblasti pracovného trhu spravilo Slovensko najväčší krok spomedzi všetkých krajín sveta a v tabul'ke krajín V4 mu patrí prvá priečka. Oblast' pracovnej legislatívy bola porovnávaná piatimi kritériami:

- Obtiažnost' prijímania - tento index meria rozsah zmluvy na dobu určitú (či sa vzt’ahuje len na dočasné úlohy), maximálnu dížku trvania zmluvy na dobu určitú a podiel minimálnej mzdy k priemernej pridanej hodnote na pracovníka.

- Obtiažnost' prepúšstania - tento index v sebe zahŕňa osem častí - či je nadbytok dostatočný dôvod na prepúšt’anie, či zamestnanec musí ohlásit' odborom prepustenie nadbytočného zamestnanca resp. to isté pre hromadné prepúšt'anie, či zamestnanec potrebuje súhlas odborov na prepustenie nadbytočného zamestnanca resp. to isté pre hromadné prepúšt’anie, či zákon vyžaduje uprednostnit' rekvalifikáciu alebo inú pozíciu pred prepustením, či je možné aplikovat' prednostné právo pri prepúšt’aní a tiež pri spätnom zamestnaní pracujúceho.

- Rigidnost' pracovného času - index skúma pät' oblastí - existenciu nočnej zmeny, práce cez víkendy, či dížka pracovného týždňa je 5,5 dňa alebo viac, či je povolené predíženie pracovného dňa na 12 hodín (vrátane nadčasov), či ročná dížka platenej dovolenky je 21 dní alebo menej.

- Rigidinost' pracovného pomeru - tento index je jednoduchým aritmetickým priemerom predchádzajúcich troch indexov - hodnoty indexov sa pohybujú v rozpätí 0 až 100, pričom najlepšou hodnotou je 0 a najhoršou 100.

- Náklady na prepustenie - sú vyjadrené v týždňoch, ktoré musí platit' zamestnanec odchádzajúcemu zamestnancovi vo forme odstupného.

Tabul'ka 2 Pružnost' trhu práce na Slovensku v porovnaní so sledovanými krajinami

\begin{tabular}{|l|l|l|l|l|l|}
\hline Krajina & $\begin{array}{l}\text { Obtiažnost' } \\
\text { prijímania } \\
\text { zamestnancov }\end{array}$ & $\begin{array}{l}\text { Obtiažnost' } \\
\text { prepúšt'ania } \\
\text { zamestnancov }\end{array}$ & $\begin{array}{l}\text { Stuhlost’ } \\
\text { pracovného } \\
\text { casu }\end{array}$ & $\begin{array}{l}\text { Stuhlost' } \\
\text { pracovného } \\
\text { pomeru }\end{array}$ & $\begin{array}{l}\text { Náklady } \\
\text { prepustenie } \\
\text { (v týždňoch) }\end{array}$ \\
\hline Slovensko & 0 & 20 & 10 & 10 & 17 \\
\hline Česká republika & 44 & 20 & 20 & 28 & 22 \\
\hline Mad'arsko & 11 & 80 & 30 & 40 & 34 \\
\hline Pol'sko & 11 & 60 & 30 & 34 & 25 \\
\hline
\end{tabular}




\section{Registrovanie nehnutel'ností}

Úroveň registrácie a zverejňovania majetkových práv ovplyvňuje prístup podnikatel'a k finančným prostriedkom. Nehnutel'nosti pre banky znamenajú dobrú zábezpeku, na základe ktorej môžu poskytnút' úver. Situácia v oblasti registrácie nehnutel'ností sa vo svete výrazne odlišuje. V rozvojových krajinách je problémom už to, že vel'ká čast' nehnutel'ností nie je formálne evidovaná. Rozdielnost' je však aj v tom, že ak si chce podnikatel' napríklad kúpit' určitú nehnutel'nost', v každej krajine potrebuje absolvovat' iný počet krokov, čo si vyžaduje rôzny čas, potrebný na zmenu vlastníckych práv a tiež prináša rozdielne náklady.

Na porovnanie krajín Vyšehradskej štvorky použijeme tri ukazovatele:

- počet procesov potrebných na registráciu;

- počet dní potrebných na registráciu;

- náklady spojené $\mathrm{s}$ registráciou, vyjadrené $\mathrm{v}$ percentuálnom pomere k hodnote nehnutel'nosti - tieto náklady vznikajú najmä vo forme daní, poplatkov za registráciu a tiež poplatkov notárovi.

Slovensko sa môže pochválit’ rýchlou registráciou, no ukazovatel' nákladov má oproti svojmu severnému susedovi takmer dvojnásobný.

Tabul'ka 3 Registrácia nehnutel'ností v SR v porovnaní so sledovanými krajinami

\begin{tabular}{|l|l|l|l|}
\hline Krajina & Počet procedúr & Počet dní & $\begin{array}{l}\text { Náklady (percentuálny podiel na } \\
\text { hodnote nehnutel'nosti) }\end{array}$ \\
\hline Slovensko & 5 & 22 & 3,1 \\
\hline Česká republika & 4 & 122 & 3,0 \\
\hline Mad’arsko & 4 & 79 & 6,8 \\
\hline Pol'sko & 7 & 204 & 1,6 \\
\hline
\end{tabular}

\section{Prístup k úverom}

Úvery sú vel'mi častým riešením nedostatku peňazí, najmä v podnikatel’skom prostredí. Rozhodovanie o poskytnutí resp. neposkytnutí úveru pre banku je vel'mi zodpovedná činnost', poučením môže byt' aj nedávna história v Slovenskej republike, kedy vd’aka zlým úverom ostali najväčšie bankové domy na pokraji krachu. Pri posudzovaní žiadostí o úver bankárom vel'mi pomáha úverový register, v ktorom vidia úverovú minulost' potenciálneho klienta, na základe ktorej l’ahšie dokážu odhadnút' riziko poskytnutia úveru tomuto klientovi. Aj preto Svetová banka pri porovnávaní úverového prostredia krajín kladie najväčší dôraz práve na existenciu a kvalitu registrov.

K porovnávaniu sledovaných krajín pristúpime pomocou nasledujúcich piatich ukazovatel'ov:

- Náklady na vytvorenie záruky - vytváranie a registrácia hnutel’ných záruk sú v mnohých krajinách lacné a rýchle, no niekedy za cenu absencie registra záruk, čo znemožňuje overit' si právo na danú záruku. Tento ukazovatel' je pomerom nákladov k príjmu na osobu.

- Index legálnych práv - práva dlžníka a veritel’a v oblasti záruk definujú, kto kontroluje proces, kto má nárok na dlžníkove aktíva, d’alej zahŕňajú aj legislatívu v oblasti bankrotu. Index dosahuje hodnoty v rozpätí 0 (najhoršia hodnota) až 10 (najlepšia hodnota).

- Index úverových informácií - v sebe zahŕňa vyspelost' úverových registrov z hl'adiska toho, aké informácie zverejňuje, či je elektronický a podobne. Dosahuje hodnoty od 0 po 6 , pričom podobne ako predchádzajúci index, čím vyššia hodnota indexu, tým lepší úverový register krajina má.

- Rozsah verejného registra (na 1000 dospelých). 
- Rozsah súkromného úradu (na 1000 dospelých).

Tabul'ka 4 Úverové prostredie na Slovensku v porovnaní so sledovanými krajinami

\begin{tabular}{|l|lr|l|l|l|l|}
\hline & $\begin{array}{l}\text { Náklady nytvorenie } \\
\text { Krajina }\end{array}$ & $\begin{array}{l}\text { záruky } \\
\text { z príjmov } \\
\text { osobu) }\end{array}$ & $\begin{array}{l}\text { Index } \\
\text { legálnych } \\
\text { práv } \\
(0-10)\end{array}$ & $\begin{array}{l}\text { Index } \\
\text { úverových } \\
\text { informácí́ } \\
(0-6)\end{array}$ & $\begin{array}{l}\text { Rozsah } \\
\text { verejného } \\
\text { registra (na 1000 } \\
\text { dospelých) }\end{array}$ & $\begin{array}{l}\begin{array}{l}\text { Rozsah } \\
\text { (nákromného úradu } \\
\text { dospelých) }\end{array} \\
1000\end{array}$ \\
\hline Slovensko & 20,1 & 9 & 3 & 6 & 0 \\
\hline Česká republika & 0,6 & 6 & 5 & 21 & 249 \\
\hline Mad'arsko & 13,5 & 5 & 3 & 0 & 33 \\
\hline Pol'sko & 1,2 & 2 & 5 & 0 & 380 \\
\hline
\end{tabular}

\section{Ochrana investorov}

Existuje aj druhý základný princíp získavania finančných prostriedkov - kapitálové financovanie. Ide o prípad, kedy podnik získa investora, ktorý vloží financie do základného imania. Pôvodní majitelia týmto krokom síce znižujú svoje rozhodovacie právomoci, na druhej strane však nemusia splácat' žiadny úver ani úroky. V bohatých krajinách získavajú štartujúce podniky a štát finančné prostriedky na finančných trhoch. V rozvojových krajinách to robia len vel'ké etablované spoločnosti a štát. Je to spôsobené aj vel'kost'ou trhov. Na americkej burze sa napríklad obchoduje s 5300 spoločnost'ami pri celkovej trhovej kapitalizácii vyše 14 biliónov dolárov. Oproti tomu napríklad burza v Saudskej Arábii obchoduje so sedemdesiatimi spoločnost’ami a trhová kapitalizácia je oproti USA 90-krát nižšia. Hoci burzy fungujú vo vyše 100 krajinách, len v štyridsiatich znamenajú burzy reálnu cestu k získaniu kapitálu.

Potenciálny investor sa vystavuje riziku, že o svoje peniaze príde v dôsledku „vytunelovania“ spoločnosti. Bezpečnost' tejto formy financovania je možné zvýšit' dostupnost'ou informácií o majetkových pomeroch vlastníkov a finančnej činnosti podniku, existenciou dozornej rady či zákonom, umožňujúcim vykonávat' v podnikoch previerku externými audítormi. Štúdia Doing Business oblast' ochrany investorov porovnáva súhrnným indexom, ktorý za splnenie každej zo siedmich podmienok pridel'uje danej krajine jeden bod. Index teda nadobúda hodnoty od 0 (žiadna ochrana pre investorov) po 7 (bezpečné prostredie na investovanie). Ide o nasledujúcich sedem podmienok:

1. Vlastnícke vzt’ahy rodinných príslušníkov sú odhalené.

2. Nepriame vlastníctvo je odhalené.

3. Tiché vlastníctvo je odhalené.

4. Hlasovacie práva medzi akcionármi sú odhalené.

5. Dozorná rada musí byt' schválená.

6. Externí audítori musia hodnotit' spoločnost'.

7. Informácie o vlastníctve aj finančných tokoch sú zverejnené.

Krajinou, ktorá sa môže pochválit' vel'mi silnou ochranou investorov, je Vel'ká Británia, ktorej index dosahuje maximálnu hodnotu 7, čiže spĺňa všetkých sedem podmienok. Okrem nej túto hodnotu dosahujú aj Kanada, Izrael, Španielsko a USA. Na opačnom póle sú Kambodža a Honduras, ktoré nespĺńajú ani jednu podmienku. Z nasledujúcej tabul'ky je vidno, že Slovensko aj Česká republika sú na tom v oblasti ochrany investorov v súčasnosti vel'mi dobre. 
Tabul'ka 5 Ochrana investorov v SR v porovnaní so sledovanými krajinami

\begin{tabular}{|l|l|}
\hline Krajina & Index ochrany investorov $(0-7)$ \\
\hline Slovensko & 6 \\
\hline Česká republika & 6 \\
\hline Mad'arsko & 5 \\
\hline Pol'sko & 4 \\
\hline
\end{tabular}

\section{Vymožitel'nost' práva}

V niektorých krajinách prakticky nie je možné dovolat' sa práva na súdoch. Dlžníci nemusia splácat' svoje záväzky, pretože vedia, že súdy ich k tomu neprinútia. Problém však nie je ani tak v samotných sudcoch, ako v byrokratických procedúrach, ktorým sudcovia a tiež strany v procese čelia. Neefektívnost' súdov samozrejme brzdí rozvoj podnikania, preto by malo byt' v záujme každej krajiny čo najviac zefektívňovat' výkon súdnej moci. Efektívnost' slovenských súdov je aj v rámci V4 nedostatočná. Nebyt' „nekonečných“ procesov v Pol'sku, Slovensko by bolo na chvoste regiónu.

Tabul'ka 6 Vymožitel'nost' práva na Slovensku v porovnaní so sledovanými krajinami

\begin{tabular}{|l|l|l|l|}
\hline Krajina & Počet procedúr & Dížka trvania procesu v dňoch & Náklady (v \% z dlhu) \\
\hline Slovensko & 27 & 565 & 15,0 \\
\hline Česká republika & 22 & 300 & 9,6 \\
\hline Mad'arsko & 21 & 365 & 8,1 \\
\hline Pol'sko & 41 & 8000 & 8,7 \\
\hline
\end{tabular}

Spomeňme si ešte jednu zaujímavost', spojenú s nákladmi na súdne vymáhanie pohl'adávky. V Kongu sa dlh vymáhat' prakticky neoplatí, pretože náklady spojené s jeho vymožením dosahujú 2,5-násobok samotného dlhu. V porovnaní s touto africkou krajinou sme na tom stále vel'mi dobre.

\section{Skončenie podnikania}

Mnohým podnikatel'om sa podarí na trhu presadit' až na druhý alebo tretí pokus. Preto by mali mat' podnikatelia možnost' $\mathrm{v}$ prípade neúspechu efektívne skončit' podnikanie a čo najskôr začat' znovu podnikat'. Vel'mi často ich však vo svojej snahe zabrzdí zdíhavý a nákladný priebeh konkurzného konania. Samotné konkurzné konanie je na Slovensku v súčasnosti pocit’ované ako problém, najmä pre svoju netransparentnost'. Legislatíva bola upravovaná mnohokrát, no nájst' vyhovujúcu podobu je zatial' u nás problémom. V regióne má naša krajina druhú najvyššiu mieru návratnosti, zlepšit' by však mala najmä dížku procesu.

Oblast' skončenia podnikania budeme porovnávat' v sledovaných krajinách tromi ukazovatel'mi:

- čas potrebný na zrušenie firmy (v rokoch),

- náklady na skončenie podnikania (v \% z konkurznej podstaty),

- miera návratnosti - vyjadruje, kol'ko centov z jedného dolára sa vráti veritel’om, zamestnancom a úradom.

Tabul'ka 7 Skončenie podnikania na Slovensku v porovnaní so sledovanými krajinami

\begin{tabular}{|l|l|l|l|}
\hline Krajina & $\begin{array}{l}\text { Čas potrebný na zrušenie } \\
\text { podniku (v rokoch) }\end{array}$ & $\begin{array}{l}\text { Náklady spojené s ukončením } \\
\text { podnikania (v\% z hodnoty majetku) }\end{array}$ & Miera návratnosti \\
\hline Slovensko & 4,7 & 18 & $39,6 \%$ \\
\hline Česká republika & 9,2 & 18 & $16,8 \%$ \\
\hline Mad'arsko & 2,0 & 23 & $30,8 \%$ \\
\hline Pol'sko & 1,4 & 18 & $68,2 \%$ \\
\hline
\end{tabular}




\section{Literatúra}

[1] Národná agentúra pre rozvoj malého a stredného podnikania: Podnikatel'ské prostredie na Slovensku 2004. NARMSP. Bratislava. 2004. ISBN: 80-88957-35-4.

[2] Epping, R. Ch.: Sprievodca globálnou ekonomikou. Portál. Praha. 2004. ISBN: 80-7178$825-2$.

[3] The International Bank for Reconstruction and Development, The World Bank: Doing Business in 2005. Washington. 2005.

[4] SARIO: Zákonník práce. [online]. [Citované 2006-02-26]. Dostupné na: $<$ http://www.sario.sk/swift_data/source/dokumenty/zakonnik_prace.pdf $>$ 